\title{
A Modified Technique for the Treatment of Isthmic Spondylolisthesis
}

\section{İstmik Spondilolistezis Tedavisinde Kullanulan Bir Modifiye Teknik}

\author{
Tevfik YILMAZ ${ }^{1}$, Sedat DALBAYRAK², Onur YAMAN², Mesut YILMAZ², Murat AYTEN², Yahya TURAN¹, \\ Kadir OZTURK ${ }^{2}$ \\ ${ }^{1}$ Dicle University, School of Medicine, Department of Neurosurgery, Diyarbakir, Turkey \\ ${ }^{2}$ Neurospinal Academy, Department of Neurosurgery, Istanbul, Turkey \\ ${ }^{3}$ Tepecik Education and Research Hospital, Department of Neurosurgery, Izmir, Turkey
}

Corresponding Author: Tevfik YILMAZ / E-mail: kartaltevfik@hotmail.com

\begin{abstract}
AIM: To describe a modified technique for the treatment of single level, isthmic spondylolisthesis (IS)

MATERIAL and METHODS: Forty-two patients who underwent posterior lumbar interbody fusion (PLIF) with spinolaminar autologous bone graft for the treatment of isthmic spondylolisthesis between May 2007 and November 2011, were retrospectively reviewed. All patients underwent total removal of the spinolaminar process, total discectomy and endplate decortication, and proper size spinolaminar autologous bone graft was sequentially inserted into the disc space with posterior instrumentation. Outcomes of the study included visual analogue scale (VAS), Oswestry disability index (ODI), and radiographic fusion.

RESULTS: The average duration of follow-up was 3.5 years. Neither has implant failure been observed nor has revision been required so far. The mean Oswestry Disability Index improved from 53\% to 9.5\%, and visual analog scale for back pain from 8.5 to 3.8 at the first month and 1.3 at the sixth month postoperatively. Visual analog scale for leg pain from 8.3 to 1.4 at the first month and 0.8 at the sixth month postoperatively. All patients had clinical and radiographic evidence of solid fusion without any need for revision.
\end{abstract}

CONCLUSION: The modified posterior lumbar interbody fusion and posterior instrumentation technique is a safe and effective treatment for isthmic spondylolisthesis.

KEYWORDS: Isthmic spondylolisthesis, Posterior lumbar interbody fusion, Autologous bone greft

öz

AMAÇ: Tek seviye istmik spondilolistezisi olan hastalarda kullanılan modifiye edilmiş bir tekniği tanımlama.

YÖNTEM ve GEREÇLER: Mayıs 2007 ile Kasım 2011 yılları arasında istmik spondilolistezisi olan spinolaminar otogreft ile posterior interbody füzyon (PLIF) uygulanan 42 hasta geriye dönük olarak incelendi. Hastalarda spinolaminer çıkıntı tamamen çıkarıldı. Disk mesafesi boşaltıldıktan ve dekortikasyon yapıldıktan sonra mesafeye uygun spinolaminer otolog kemik greft yerleştirilerek redüksiyon sonrası posterior enstrümantasyon yapıldı. Hastaların cerrahi sonrası ağrıları görsel ağrı skalası (GAS) ve Oswestry disability indeksleri (ODI) ve füzyonları radyolojik olarak değerlendirildi.

BULGULAR: Ortalama takip süresi 3,5 yıl idi. Hastaların hiçbirinde implant yetmezliği ve revizyon ihtiyacı görülmedi. Oswestry Disability Index (ODI) \%53'den \%9,5'a düştü. Bel ağrısı için görsel ağrı skalası (GAS) 8.5'dan 1. ayda 3,8'e, 6. ayda 1,3'e düştü. Bacak ağrısı için GAS 8,3'den 1. ayda 1,4'e, 6. ayda 0,8'e düştü. Hastaların tamamında klinik ve radyolojik olarak solid füzyonun olduğu tespit edildi.

SONUÇ: Modifiye edilmiş posterior lomber interbody füzyon ve posterior enstrümantasyon istmik spondilolistezisin tedavisinde kullanılan etkili ve güvenli bir yöntemdir.

ANAHTAR SÖZCÜKLER: İstmik spondilolistezis, Posterior lomber interbody füzyon, Otogen kemik greft

\section{INTRODUCTION}

Isthmic spondylolisthesis (IS) is one of the most common causes of low back pain and sciatica in adolescents and adults. IS has an effect on nearly $6 \%$ of the general population, and it leads to significant morbidity and loss of labor. L5-S1 and L4-L5 levels are the most frequently involved segments, respectively (18).

Surgical treatment is indicated in case of failure to relieve persistent back and/or radicular pain after 6 months of conservative treatment, progressive neurological deficit or neurogenic claudication, symptomatic grade III or IV slip, spondyloptosis, and progressive deformity $(10,17)$.

The ideal surgical treatment for isthmic spondylolisthesis is still controversial. Although a number of autograft and allograft materials are used in addition to various types of cage systems, the optimal fusion material for this purpose is still unclear. On the other hand, there seems to be no consensus either on the application of reduction or on the 
determination of fusion level. There are on-going studies that aim to find an ideal surgical approach to achieve perfect radiological and clinical results.

\section{MATERIAL and METHODS}

We retrospectively reviewed data from 42 selected patients, who had been surgically treated for adult isthmic spondylolisthesis between May 2007 and November 2011. The inclusion criterion required that the patient have single-level IS without degenerative disease in the adjacent level. The exclusion criteria were multilevel IS, other spinal deformity and previous lumbar spine surgery. There were 14 males and 28 females, aged between 20 and 66 (mean age was 49) at the time of the surgery. The spondylolisthesis levels were diagnosed at L3-L4 in 2 cases; L4-L5 in 10 cases; and L5-S1 in 30 cases (Table I). All patients considered for surgical treatment had persistent back and/or leg pain, lower extremity pain, progressive neurological deficits or neurological intermittent claudication, which were refractory to conservative treatment for not less than 6 months.
Before surgery, all patients were examined by standing plain radiograph including, anteroposterior, lateral and both oblique X-Rays computed tomography scanning (CT). Lateral flexion and extension X-Rays were taken to see if there was any instability, and MRI was obtained to see if there were any degenerative changes at the intervertebral disc (Figures $1,2 A-C)$. The preoperative data were collected regarding Meyerding grade, slip angle.

The quality of bone fusions at the intervertebral spaces were evaluated by anteroposterior and lateral images and a special scale developed for fusion assessment. According to this scale, no sign of fusion was rated as 1 , bone formation in the anterior and posterior portions of the vertebral corpora and presence of hyperdense areas over the sites where bone graft or contacts with the superior and inferior end-plates was rated as 2, whereas patients who demonstrated a disc space completely filled with bone formation in a solid fashion were rated as 3 .

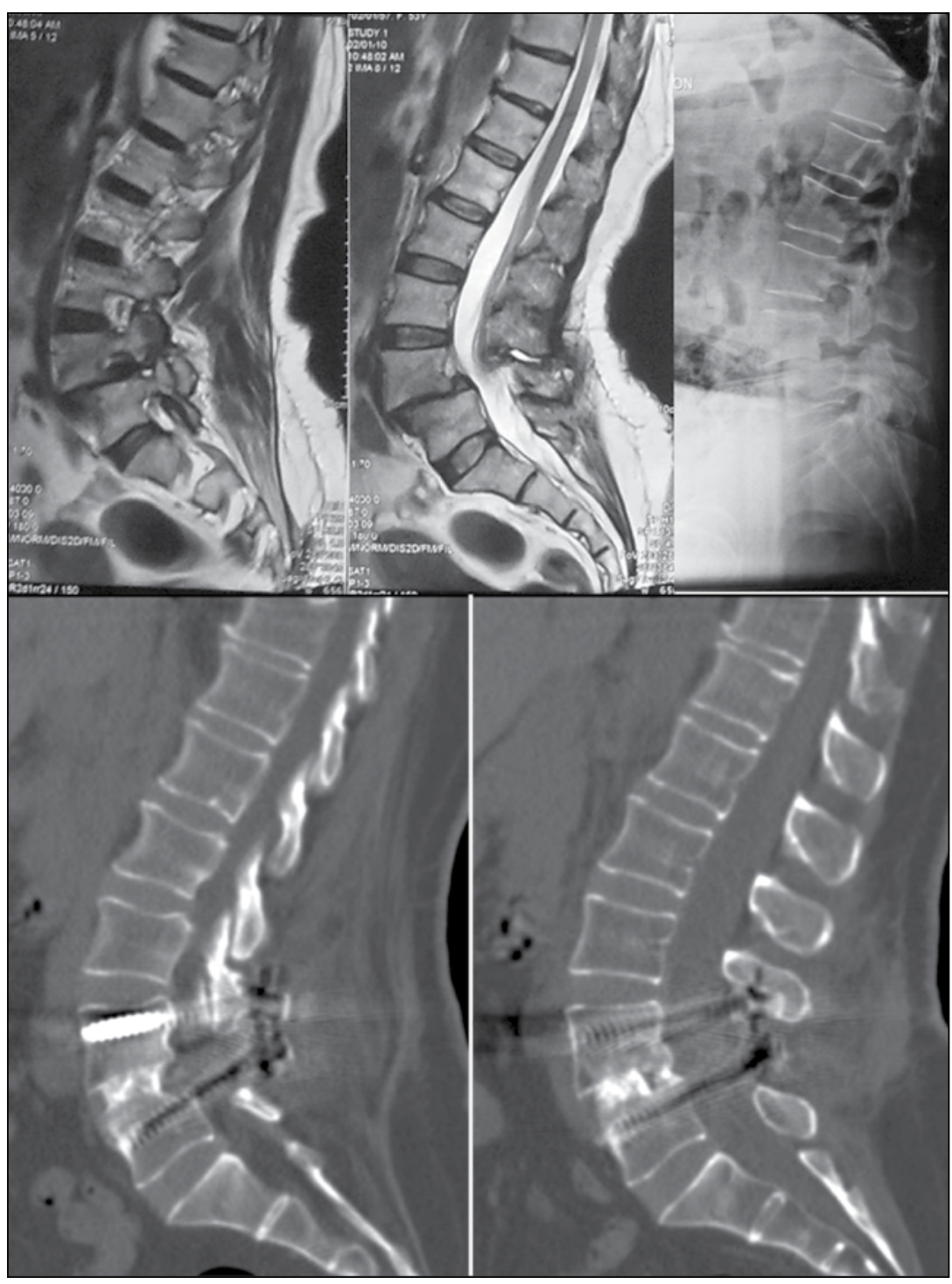

Figure 1: L4-5 isthmic spondylolisthesis. Preoperative spinopelvic harmony increased from 6 degrees to 17 degrees postoperatively (Case 23). 
Table I: Features of the Patients

\begin{tabular}{|c|c|c|c|c|c|c|}
\hline Case & $\begin{array}{c}\text { Age (year)/ } \\
\text { Gender }\end{array}$ & Level & $\begin{array}{c}\text { Mean } \\
\text { follow-up } \\
\text { (months) }\end{array}$ & $\begin{array}{l}\text { Meyerding } \\
\text { Grade }\end{array}$ & $\begin{array}{c}\text { Time of Surgery } \\
\text { (minutes) }\end{array}$ & $\begin{array}{l}\text { Blood Loss } \\
\text { (cc) }\end{array}$ \\
\hline Case 1 & $20 / M$ & L4-5 & 50 & 1 & 220 & 1200 \\
\hline Case 2 & $40 / F$ & LS-S1 & 40 & 1 & 220 & 1900 \\
\hline Case 3 & $38 / F$ & L5-S1 & 24 & ॥ & 210 & 700 \\
\hline Case 4 & $52 / \mathrm{M}$ & L5-S1 & 46 & I & 240 & 1800 \\
\hline Case 5 & $46 / F$ & L4-5 & 50 & II & 240 & 2000 \\
\hline Case 6 & $54 / F$ & L3-4 & 66 & I & 210 & 1100 \\
\hline Case 7 & $42 / F$ & L5-S1 & 65 & I & 210 & 1000 \\
\hline Case 8 & $52 / F$ & L5-S1 & 36 & I & 240 & 1600 \\
\hline Case 9 & $66 / M$ & L5-S1 & 30 & ॥ & 230 & 2100 \\
\hline Case 10 & $46 / F$ & L5-S1 & 40 & I & 210 & 1800 \\
\hline Case 11 & $48 / F$ & L4-5 & 50 & I & 240 & 1400 \\
\hline Case 12 & $54 / F$ & L3-4 & 40 & I & 220 & 1800 \\
\hline Case 13 & $60 / F$ & L4-5 & 32 & I & 270 & 1900 \\
\hline Case 14 & $51 / \mathrm{M}$ & L5-S1 & 54 & II & 260 & 2400 \\
\hline Case 15 & $63 / F$ & L5-S1 & 24 & 1 & 230 & 2200 \\
\hline Case 16 & $51 / \mathrm{M}$ & L5-S1 & 46 & II & 240 & 2200 \\
\hline Case 17 & $54 / F$ & L5-S1 & 25 & II & 250 & 2000 \\
\hline Case 18 & $60 / F$ & L5-S1 & 35 & 1 & 220 & 1800 \\
\hline Case 19 & $62 / F$ & L5-S1 & 45 & I & 210 & 1000 \\
\hline Case 20 & $54 / M$ & L5-S1 & 35 & 1 & 240 & 1600 \\
\hline Case 21 & $56 / F$ & L5-S1 & 68 & III & 230 & 3000 \\
\hline Case 22 & $44 / F$ & L5-S1 & 60 & 1 & 210 & 1000 \\
\hline Case 23 & $46 / F$ & L4-5 & 35 & I & 250 & 1400 \\
\hline Case 24 & $37 / M$ & L5-S1 & 78 & II & 240 & 1900 \\
\hline Case 25 & $44 / F$ & L5-S1 & 47 & I & 250 & 1000 \\
\hline Case 26 & $60 / M$ & L5-S1 & 48 & I & 250 & 1200 \\
\hline Case 27 & $51 / F$ & L5-S1 & 42 & I & 250 & 1400 \\
\hline Case 28 & $52 / F$ & L4-5 & 46 & II & 240 & 2000 \\
\hline Case 29 & $48 / F$ & L5-S1 & 34 & I & 250 & 1900 \\
\hline Case 30 & $60 / M$ & L5-S1 & 52 & II & 260 & 2100 \\
\hline Case 31 & $44 / M$ & L4-5 & 56 & II & 250 & 2000 \\
\hline Case 32 & $46 / F$ & L5-S1 & 42 & I & 240 & 1800 \\
\hline Case 33 & $44 / M$ & L5-S1 & 53 & II & 240 & 2100 \\
\hline Case 34 & $54 / \mathrm{M}$ & L5-S1 & 24 & I & 250 & 1200 \\
\hline Case 35 & $38 / F$ & L4-5 & 34 & I & 250 & 1800 \\
\hline Case 36 & $41 / F$ & L5-S1 & 30 & 1 & 240 & 1400 \\
\hline Case 37 & $41 / F$ & L5-S1 & 32 & II & 280 & 2000 \\
\hline Case 38 & $35 / M$ & L4-5 & 44 & I & 240 & 1800 \\
\hline Case 39 & $54 / F$ & L5-S1 & 40 & II & 240 & 2200 \\
\hline Case 40 & $34 / F$ & L5-S1 & 26 & I & 240 & 1200 \\
\hline Case 41 & $32 / \mathrm{M}$ & L4-5 & 42 & III & 240 & 3500 \\
\hline Case 42 & $61 / F$ & L5-S1 & 30 & III & 360 & 4200 \\
\hline
\end{tabular}




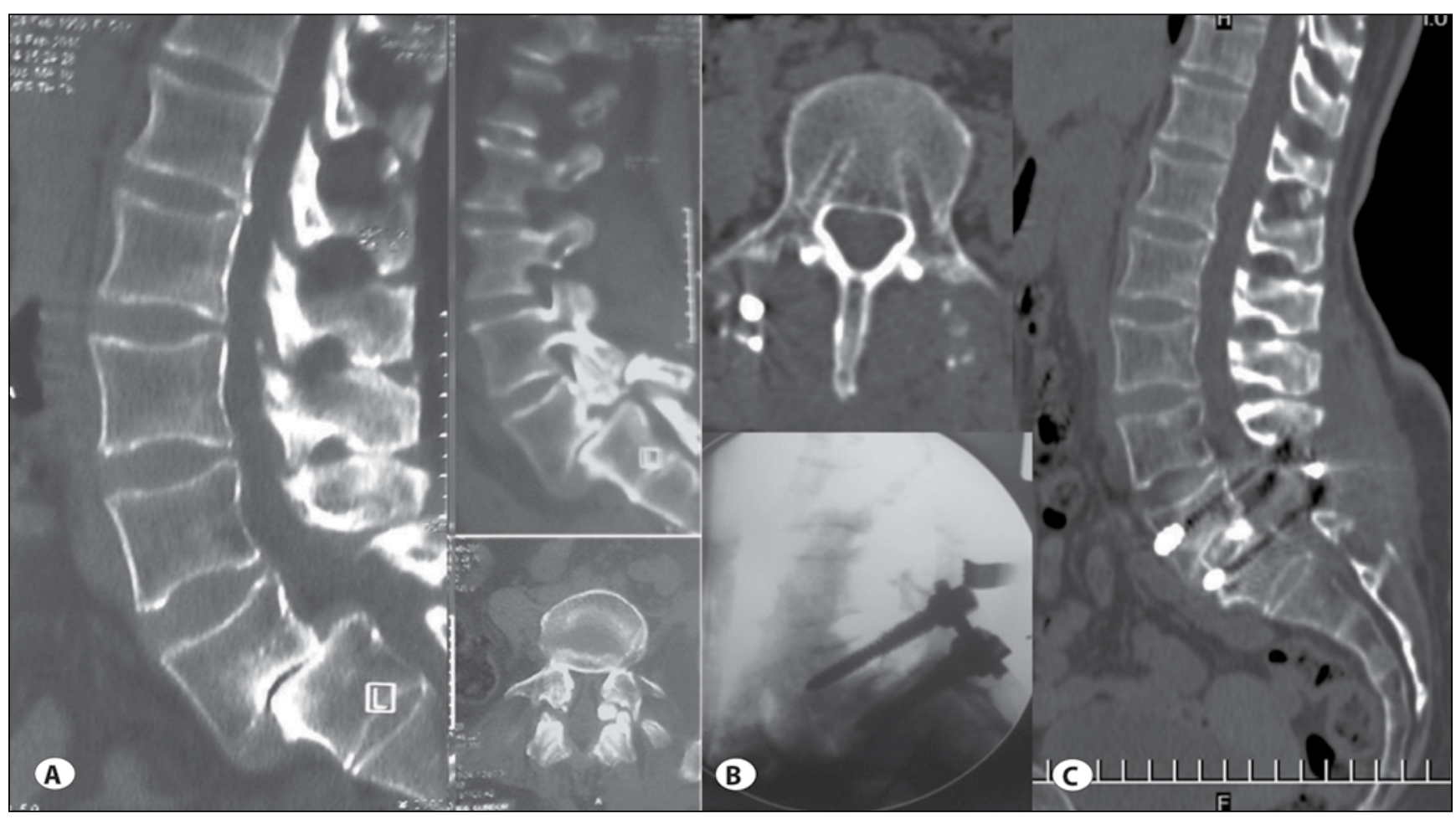

Figure 2: Grade 2 isthmic spondylolisthesis. A) Preoperative CT images B) Up; reduction of the listhetic segment with the help of pilot screw, Down; fluoroscopic prints of the pilot screws C) Postoperative sagittal CT images (Case 5).

Each patient had a standing lateral radiograph before the surgery and following the surgery, including the spine from the T10 vertebra to the sacrum and the femoral heads. The spino-pelvic parameters were measured as follows:

Pelvic incidence (PI): The angle between the vertical line drawn from the sacral upper end plate and the bi-coxo-femoral line.

Sacral slope (SS): The angle between the upper end plate of S1 and the horizontal line.

Lumbar lodorsis (LL): The angle between the upper end plate of T12 to the upper end plate of S1 in the sagittal plane. (Figure 3).

\section{Surgical Technique}

Posterior lumbar interbody fusion (PLIF), instrumentation and nerve root decompression were performed on all patients. The fusion and instrumentation were limited to the listhetic segment. The surgical technique was the one described by Cloward. In all patients, after a standard posterior midline incision was made for the exposure of the involved vertebra, the pseudarthrosis of pars articularis was identified, and the patients underwent complete removal of the total spinolaminar process and fibrocartilaginous tissue (Figure 4). Ligamentum flavum was resected bilaterally, and the nerve root was decompressed far distally and laterally. Two pedicular screws were placed on both sides of the slipped vertebra and upper vertebra (Figure 5). Complete discectomy and endplate decortication were performed, and a previously prepared proper size spinolaminar autologous bone graft was sequentially inserted into the disc space (Figure 5). The screws were then connected with a rod, and reduction was performed for the slipped vertebra (Figure 5). The involved segment was distracted. Guided by fluoroscopy, the system was tightened until the spondylolisthesis was completely reduced. Both rods were mounted under slight compression. At this stage, a radiograph confirmed near anatomic reduction of the spondylolisthetic segment and restoration of normal lordosis (Figure 5). Next, the canal and foramen were examined.

\section{RESULTS}

The procedure was completed successfully in all patients. None of the patients had permanent neurologic deficit or pseudarthrosis at the time of last follow-up. PLIF and anatomical reduction were achieved in all patients (Figure 1, $2 \mathrm{~A}-\mathrm{C}$ ). The mean operating time was 240 minutes (range, 210 min. to $360 \mathrm{~min}$.), and the mean blood loss was $1600 \mathrm{cc}$ (range, 700 to $4200 \mathrm{cc}$ ). We started ambulation after the second day of bed rest. The patients wore thoraco-lumbar-sacral orthosis for at least 3 months. The follow up period was more than 2 years. The average clinical and radiologic follow-up interval was 42 months (range, 24 to 78 months).

Preoperative lumbar lordosis was measured a minimum 60 degrees and maximum 77 degrees (mean 69.2 degrees), while postoperative minimum lumbar lordosis was found to be a minimum of 40 degrees and the maximum was 62 degrees (mean 50.6 degrees). The normal range is $60+/-15$ degrees. 

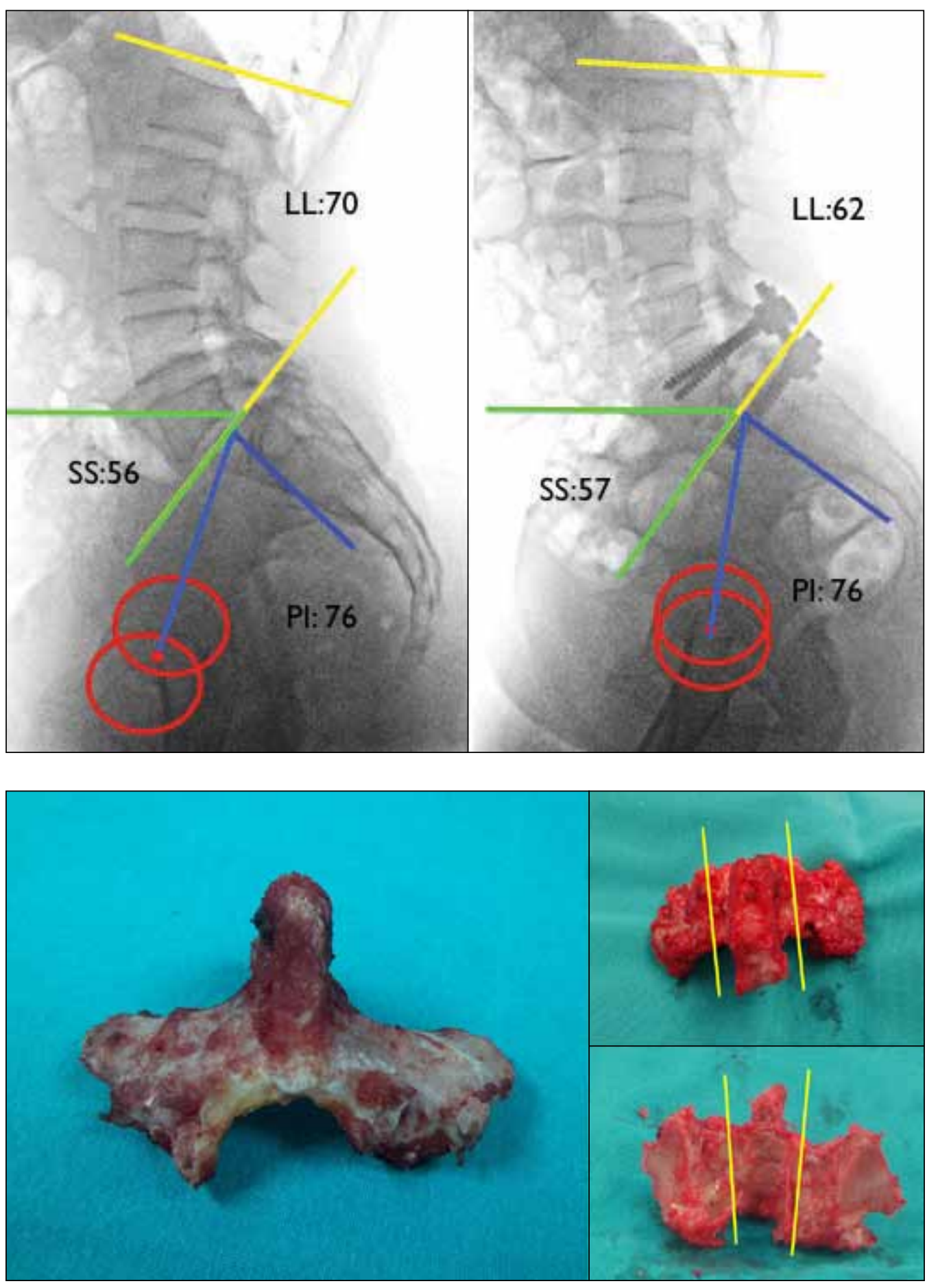

Figure 3: Measurements of spinopelvic parameters. (Before and after the surgery). PI: Pelvic Incidence, SS: Sacral slope, LL: lumbar lordosis
Figure 4: Removal of the total spinolaminar process.
Preoperative sacral slope was minimum 17, maximum 58 degrees (mean 43 degrees), while postoperative minimum sacral slope was minimum 32 degrees and maximum was 57 degrees (mean 42 degrees). Sacral slope range was $39.6+/-$ 7.9 degrees.

Preoperative and postoperative pelvic incidence was minimum 42, maximum 79 degrees (mean 66.4 degrees). Normal range is $52.6+/-10.4$ degrees.

\section{Radiological Outcomes}

Radiologic evidence of successful arthrodesis was noted in all patients (100\%) for the PLIF (Figure 1, 2A-C). It was radiographically considered that the spines of all patients were fused by the $6^{\text {th }}$-month postoperative visit, given the evidence indicating visible incorporation of the spinolaminar autologous bone graft, maintenance of the reduction, and the absence of instrumentation- related adverse events. 
The operating surgeons used anterior-posterior, lateral flexion-extension films, and thin-slice multiplanar computed tomography scans to evaluate the integrity of the fusion mass (Figure 1, 2A-C). Criteria for the successful fusion included lack of motion, anterior bridging bone and lack of lucencies on flexion/extension X-rays and/or contiguous bone through the bone using a thin-cut sagittal CT scan, and no loosening or breakage of implants. All patients in this study were followed for minimum 2 years (median follow-up duration was 42 months). Mean bone fusion score was 0 at 1 month, $1.35 \pm 0.2$ at 6 months, and $2.17 \pm 0.3$ at 12 months and $2.87 \pm 0.2$ at 24 months.

\section{Clinical and Functional Outcomes}

Patients, who had radiculopathy and/ or neurogenic claudication, obtained improvement immediately after the surgery. All patients with motor weakness recovered to normal function at the 3-month follow-up visit. Each patient's final clinical status was rated according to Oswestry Disability Index (ODI), and Visual Analog Scale (VAS) pain score was used to measure patient outcomes (Table II). At the final follow-up, the treatment group showed significant improvement in all categories. There was considerable improvement in the back pain, and the mean visual analog score improved from pre- operative average 8,5 to a postoperative average of 3.8 and 1.3 at the first and sixth months respectively. There was considerable improvement in the radicular pain, and the mean visual analog score improved from preoperative average 8.3 to a postoperative average of 1.4 and 0.8 at the first and sixth months respectively.

Two complications were seen in this series. A single dural tear occurred intraoperatively, and it was repaired primarily. One patient developed postoperative pulmonary embolism, which required antiaggregant treatment. This condition was resolved by postoperative day 15 without further consequences.

At the last follow-up, all patients were observed to have returned to their normal daily activities. There was no radiographic evidence indicating progression at the grade or angle of the slippage. Furthermore, patients included in this series did not require additional surgical intervention at more proximal levels or report new symptoms that were referable to these levels at the time of final follow-up.

\section{DISCUSSION}

IS is a rather frequent disorder leading to back pain, and several surgical approaches have been defined for its treatment.

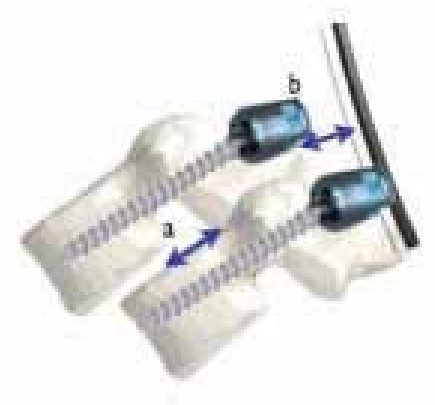

(A)

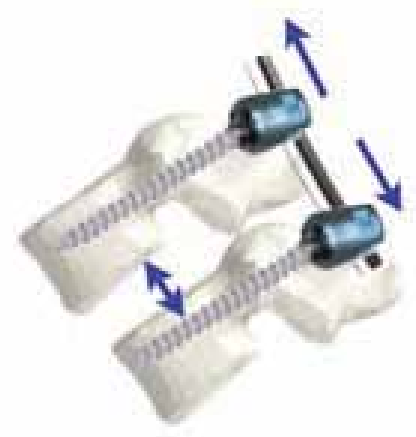

(D)

Figure 5A-E: Reduction technique of the isthmic spondylolisthesis.

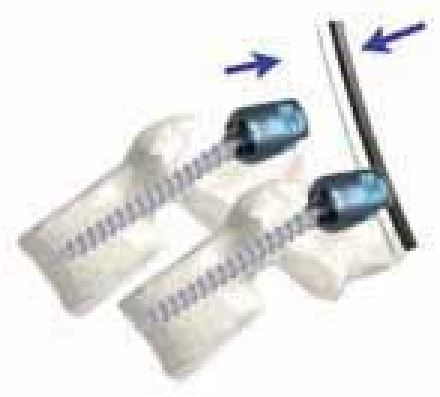

(B)

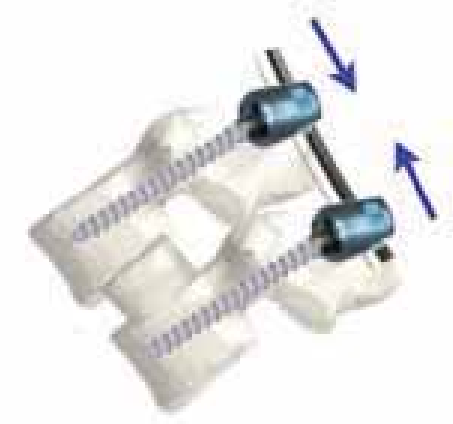

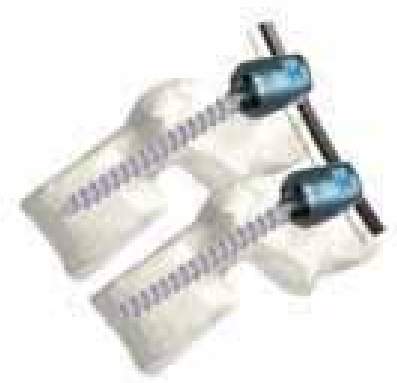

(C) 
Table II: Preoperative and Postoperative ODI and VAS of the Patients

\begin{tabular}{|c|c|c|c|c|c|c|c|c|}
\hline Case & $\begin{array}{c}\text { Pre-op } \\
\text { ODI }\end{array}$ & $\begin{array}{c}\text { Post-op } \\
\text { ODI }\end{array}$ & $\begin{array}{l}\text { Preop } \\
\text { BP.VAS }\end{array}$ & $\begin{array}{c}\text { Postop } 1^{\text {st }} \mathbf{m} \text {. } \\
\text { BP.VAS }\end{array}$ & $\begin{array}{l}\text { Postop } 6^{\text {th }} \mathrm{m} \text {. } \\
\text { BP. VAS }\end{array}$ & $\begin{array}{l}\text { Preop } \\
\text { R.VAS }\end{array}$ & $\begin{array}{c}\text { Postop } 1^{\text {st }} \mathrm{m} \text {. } \\
\text { R.VAS }\end{array}$ & $\begin{array}{c}\text { Postop } 6^{\text {th }} \mathrm{m} \\
\text { R.VAS }\end{array}$ \\
\hline Case 1 & 48 & 8 & 10 & 4 & 3 & 8 & 2 & 2 \\
\hline Case 2 & 64 & 15 & 9 & 4 & 2 & 9 & 1 & 2 \\
\hline Case 3 & 50 & 6 & 8 & 3 & 1 & 8 & 1 & 1 \\
\hline Case 4 & 50 & 8 & 7 & 2 & 0 & 8 & 1 & 1 \\
\hline Case 5 & 48 & 10 & 8 & 3 & 1 & 7 & 2 & 1 \\
\hline Case 6 & 52 & 8 & 9 & 3 & 1 & 9 & 2 & 2 \\
\hline Case 7 & 64 & 8 & 10 & 4 & 1 & 9 & 2 & 2 \\
\hline Case 8 & 62 & 10 & 8 & 3 & 0 & 8 & 1 & 2 \\
\hline Case 9 & 56 & 12 & 7 & 3 & 0 & 9 & 1 & 1 \\
\hline Case 10 & 48 & 8 & 9 & 4 & 2 & 8 & 2 & 1 \\
\hline Case 11 & 56 & 10 & 9 & 3 & 1 & 9 & 2 & 0 \\
\hline Case 12 & 54 & 14 & 8 & 3 & 0 & 8 & 1 & 1 \\
\hline Case 13 & 48 & 12 & 10 & 4 & 2 & 8 & 0 & 0 \\
\hline Case 14 & 52 & 14 & 9 & 5 & 3 & 9 & 3 & 1 \\
\hline Case 15 & 56 & 7 & 8 & 4 & 1 & 9 & 2 & 1 \\
\hline Case 16 & 60 & 8 & 7 & 4 & 1 & 8 & 2 & 0 \\
\hline Case 17 & 50 & 8 & 9 & 3 & 1 & 8 & 1 & 1 \\
\hline Case 18 & 48 & 5 & 9 & 4 & 2 & 8 & 2 & 1 \\
\hline Case 19 & 48 & 8 & 8 & 4 & 2 & 9 & 1 & 0 \\
\hline Case 20 & 62 & 14 & 7 & 3 & 1 & 9 & 2 & 1 \\
\hline Case 21 & 64 & 8 & 8 & 5 & 2 & 9 & 2 & 1 \\
\hline Case 22 & 50 & 10 & 9 & 4 & 0 & 8 & 1 & 0 \\
\hline Case 23 & 50 & 10 & 9 & 5 & 2 & 9 & 2 & 1 \\
\hline Case 24 & 60 & 7 & 10 & 4 & 1 & 9 & 1 & 1 \\
\hline Case 25 & 56 & 5 & 10 & 4 & 1 & 9 & 2 & 0 \\
\hline Case 26 & 58 & 6 & 9 & 4 & 2 & 8 & 1 & 0 \\
\hline Case 27 & 48 & 15 & 9 & 5 & 3 & 10 & 1 & 1 \\
\hline Case 28 & 48 & 7 & 8 & 4 & 1 & 9 & 2 & 1 \\
\hline Case 29 & 49 & 8 & 8 & 4 & 2 & 9 & 0 & 0 \\
\hline Case 30 & 52 & 12 & 9 & 4 & 2 & 7 & 2 & 0 \\
\hline Case 31 & 48 & 8 & 9 & 4 & 1 & 7 & 2 & 1 \\
\hline Case 32 & 50 & 14 & 10 & 5 & 2 & 9 & 3 & 2 \\
\hline Case 33 & 58 & 8 & 9 & 4 & 0 & 8 & 1 & 0 \\
\hline Case 34 & 48 & 8 & 9 & 3 & 1 & 8 & 1 & 1 \\
\hline Case 35 & 52 & 9 & 8 & 4 & 2 & 9 & 0 & 0 \\
\hline Case 36 & 60 & 6 & 9 & 5 & 2 & 8 & 2 & 1 \\
\hline Case 37 & 48 & 6 & 10 & 4 & 1 & 7 & 2 & 1 \\
\hline Case 38 & 60 & 13 & 9 & 4 & 2 & 8 & 1 & 0 \\
\hline Case 39 & 50 & 10 & 9 & 5 & 2 & 8 & 2 & 2 \\
\hline Case 40 & 52 & 9 & 8 & 4 & 0 & 9 & 0 & 1 \\
\hline Case 41 & 62 & 12 & 7 & 3 & 0 & 8 & 2 & 1 \\
\hline Case 42 & 60 & 16 & 8 & 4 & 1 & 8 & 1 & 1 \\
\hline
\end{tabular}

ODI: oswestry disability index, VAS: visual analogue scale, BP: back pain, $\boldsymbol{m}$ : month, R: radicular. 
Symptomatic isthmic spondylolisthesis usually requires surgical intervention, and the latest controversial focus is on the method and degree of reduction. Besides, the ideal fusion material and its level are still unclear. Thus, it is difficult to define the ideal surgical strategy for IS in adults based on the data published. In this paper we report satisfactory clinical and radiological results of an adult IS series treated with reduction and spinolaminar autograft in PLIF.

Lumbar IS surgery has the primary goal of neurological decompression and stability reconstruction, which includes reconstitution of the disc space height and the restoration of translational and rotational alignment in sagittal plane. The perfect technique to obtain the abovementioned goals without complication has not been discovered so far.

Fusion is another significant aspect of the surgical treatment for IS. The aim of fusion is to relieve pain by reducing the motion of the segment. Many authors have developed a number of surgical techniques to gain stability by fusion of the spondylolisthetic deformity. These include posterolateral intertransverse process fusion, ALIF, PLIF, TLIF or ELIF, transsacral cage fusion, presacral lumbar interbody fusion and combined anterior and posterior fusion $(2,3,10,11,13$, $26,27,28)$.

A lot has been written about the theoretical advantages of each approach. However, no optimal and precise approach has been established to date.

Lumbar and lumbosacral fusion using the pedicle screw system and interbody fusion (IBF) technique is a popular surgical procedure, with satisfactory clinical outcomes and high union rates $(7,21,30,33)$. Since the PLF technique is insufficient for obtaining spinal stability, a number of IBF techniques are developed such as spinous process or iliac wing autografts, allografts, cage, or their combination $(10,11$, $20,21,34)$.

The most common IBF technique is the PLIF. PLIF has been used for the treatment of spinal disorders requiring lumbar arthrodesis (5). The interbody fusion immediately produces a biomechanically stable postoperative spine. Thus, it enhances the opportunity for arthrodesis.

PLIF supports the anterior column for adequate correction and fusion. PLIF also attempts to re-establish segmental sagittal alignment through the use of an interbody fusion mass and/or cage to increase focal lordosis, yet manages to avoid the abdominal approach by conducting the surgery through a posterior approach. Other purported advantages of the PLIF technique include "360-degree" fusion, and relief of "up/down" nerve root compression within the foramen at the level of the pars defect (7)

Reduction is another issue about IS surgery, which is yet to be clarified. The role of sagittal alignment and the related possible benefits of reduction (and therefore also instrumentation) of the listhesis have not been adequately studied. Many authors advocated for it, due to the potential benefits of reduction ( 9 , $26,30)$.
The theoretical advantages of slip reduction include improved spine biomechanics, better nerve root decompression and better opportunity to obtain fusion, because it provides an increased surface area of the fusion bed, and the fusion is no longer under the influence of tension and anterior shear forces (24). Slip reduction also ensures the correction of sagittal deformity for improving posture and self-image. Realigning the spine and achieving sagittal spine balance may be important for the long term outcomes by preventing premature adjacent level disc degeneration $(1,9,12,19,29)$.

In this study, reduction was applied to all patients, and it was shown radiologically in the early and late postoperative period. We consider that successful reduction significantly influences the satisfactory clinical outcomes along with the fusion and neural decompression. Like us, Jie Pan et al. observed successful fusion in all of their patients, who underwent IS operation accompanied by reduction (24). Fusion surface increment by reduction and lumbar sagittal alignment may play an important role in achieving higher fusion rates.

One main goal of IS surgery is to obtain long-term spinal stability by fusion. The fusion success depends on the surgical approach and fusion material. Many fusion materials have been used for this purpose, but the ideal material is not clear yet. To provide fusion, various types of cages are widely used, such as intersomatic spacer, carbon cages and titanium cages $(25,30,31)$. A relatively high incidence of cage-related complications including posterior migration, infection, dural tear, non-union, and nerve injury are reported in PLIF operations $(4,8,23,31,32)$. High fusion rates have been reported for autografts. $100 \%$ fusion rates are reported in some studies, which used cages combined with iliac wing and/or spinous process autografts $(11,22,30)$. It is shown that the PLIF using autogenous bone grafting and cage fusion with pedicle screw fixation is more useful in adult spondylolisthesis for improving the fusion rate and preventing long-term instabilities, compared to the simple cage alone fusion with pedicle screw fixation (6). However iliac wing autografts cause pain and require additional incision. These studies confirm that autogenous grafts have significant positive effects on high fusion rates, while supporting our surgical technique.

In our series we used the spinolaminar process autograft as the fusion material, and this method has not been studied yet. In this method, the fusion material does not require removal in case of infection, does not increase costs, and it is not a foreign body. Besides, it achieves high fusion rates and contributes to the satisfactory clinical and radiological results.

In isthmic spondylolisthesis, pelvic incidence and sacral slope values are high $(14,16)$. Sacral end plate is more tilted, and lordosis increases. Body balance shifts forward. The angle of kyphosis decreases to ensure sagittal balance. The degree of pelvic incidence gains prognostic importance as the lysthesis progresses $(14,16)$. PI of the spondylolisthesis patients was significantly higher. This phenomenon was coincident with other studies. 
Complication rates of different surgical techniques vary among studies. In a study comparing reduction to fusion in situ with PLIF, the total complication rate was $10.2 \%$, and it was similar in two groups (21) In another paper, the complication rates of patients operated with PLF were reported as $15 \%$, and as $5.4 \%$ in patients that underwent PLF plus PLIF operation (30). The complication rate for our case series operated with our technique was found to be $4.8 \%$.

\section{CONCLUSION}

We hereby describe a novel modified PLIF method using spinolaminar process as a tricortical autogenous graft in the surgical treatment of IS. It has some advantages such as not increasing the cost for fusion material, not requiring the removal of fusion material in case of infection, high fusion rates, not containing any foreign body, high resistance against collapse thanks to the tricortical layers, provision of circumflexial fusion, possibility for single level application and not requiring adjacent segment stabilization as well as satisfactory radiological and clinical short- and long-term results. Thus, it is appropriate for use in all kinds of IS.

\section{REFERENCES}

1. Akamaru T, Kawahara N, Tim Yoon S, Minamide A, Su Kim K, Tomita K, Hutton WC: Adjacent segment motion after a simulated lumbar fusion in different sagittal alignments: A biomechanical analysis. Spine (Phila Pa 1976) 28:1560-1566, 2003

2. Baek OK, Lee SH: Extraforaminal lumbar interbody fusion for the treatment of isthmic spondylolisthesis. J Spinal Disord Tech 22:219-227, 2009

3. Bjarke Christensen F, Stender Hansen E, Laursen M, Thomsen $\mathrm{K}$, Bunger CE: Long-term functional outcome of pedicle screw instrumentation as a support for posterolateral spinal fusion: Randomized clinical study with a 5-year follow-up. Spine (Phila Pa 1976) 27:1269-1277, 2002

4. Chen L, Yang H, Tang T: Cage migration in spondylolisthesis treated with posterior lumbar interbody fusion using BAK cages. Spine (Phila Pa 1976) 30:2171-2175, 2005

5. Cloward RB: The treatment of ruptured lumbar intervertebral disc by vertebral body fusion. III. Method of use of banked bone. Ann Surg 136:987-992, 1952

6. Dou Y, Hao D, Wen S, He B: Comparison of clinical outcomes between two methods of posterior lumbar interbody fusion in adult spondylolisthesis. Zhongguo Xiu Fu Chong Jian Wai Ke Za Zhi 20:743-746, 2006

7. Edward Cunningham J, Elling EM, Milton AH, Robertson PA: What is the optimum fusion technique for adult Isthmic spondylolisthesis-PLIF or PLF? A long-term prospective cohort comparison study. J Spinal Disord Tech 26:260-267, 2013

8. Elias WJ, Simmons NE, Kaptain GJ, Chadduck JB, Whitehill R: Complications of posterior lumbar interbody fusion when using a titanium threaded cage device. J Neurosurg 93:45-52, 2000
9. Floman $\mathrm{Y}$, Millgram MA, Ashkenazi E, Smorgick $\mathrm{Y}$, Rand N: Instrumented slip reduction and fusion for painful unstable isthmic spondylolisthesis in adults. J Spinal Disord Tech 21:477-483, 2008

10. Gerszten PC, Tobler W, Raley TJ, Miller LE, Block JE, Nasca RJ: Axial presacral lumbar interbody fusion and percutaneous posterior fixation for stabilization of lumbosacral isthmic spondylolisthesis. J Spinal Disord Tech 25:E36-40, 2012

11. Gong K, Wang Z, Luo Z: Reduction and transforaminal lumbar interbody fusion with posterior fixation versus transsacral cage fusion in situ with posterior fixation in the treatment of Grade 2 adult isthmic spondylolisthesis in the lumbosacral spine. J Neurosurg Spine 13:394-400, 2010

12. Goyal N, Wimberley DW, Hyatt A, Zeiller S, Vaccaro AR, Hilibrand AS, et al: Radiographic and clinical outcomes after instrumented reduction and transforaminal lumbar interbody fusion of mid and high-grade isthmic spondylolisthesis. J Spinal Disord Tech 22:321-327, 2009

13. Hackenberg $L$, Halm H, Bullmann V, Vieth V, Schneider $M$, Liljenqvist U: Transforaminal lumbar interbody fusion: A safe technique with satisfactory three to five year results. Eur Spine J 14:551-558, 2005

14. Hanson DS, Bridwell KH, Rhee JM, Lenke LG: Correlation of pelvic incidence with low- and high-grade isthmic spondylolisthesis. Spine (Phila Pa 1976) 27(18):2026-2029

15. Harris IE, Weinstein SL: Long-term follow-up of patients with grade-III and IV spondylolisthesis. Treatment with and without posterior fusion. J Bone Joint Surg Am 69:960-969, 1987

16. Huang RP, Bohlman HH, Thompson GH: Predictive value of pelvic incidence in progression of spondylolisthesis. Spine 28:2381-2385, 2003

17. Jacobs WC, Vreeling A, De Kleuver M: Fusion for low-grade adult isthmic spondylolisthesis: A systematic review of the literature. Eur Spine J 15:391-402, 2006

18. Kalichman L, Kim DH, Li L, Guermazi A, Berkin V, Hunter DJ: Spondylolysis and spondylolisthesis: Prevalence and association with low back pain in the adult community-based population. Spine (Phila Pa 1976) 34:199-205, 2009

19. Kawakami M, Tamaki T, Ando M, Yamada $H$, Hashizume $H$, Yoshida M: Lumbar sagittal balance influences the clinical outcome after decompression and posterolateral spinal fusion for degenerative lumbar spondylolisthesis. Spine (Phila Pa 1976) 27:59-64, 2002

20. Kim JS, Kang BU, Lee SH, Jung B, Choi YG, Jeon SH, et al: Mini-transforaminal lumbar interbody fusion versus anterior lumbar interbody fusion augmented by percutaneous pedicle screw fixation: A comparison of surgical outcomes in adult low-grade isthmic spondylolisthesis. J Spinal Disord Tech 22:114-121, 2009

21. Lian XF, Hou TS, Xu JG, Zeng BF, Zhao J, Liu XK, et al: Single segment of posterior lumbar interbody fusion for adult isthmic spondylolisthesis: Reduction or fusion in situ. Eur Spine J 23(1):172-179, 2014 
22. Musluman AM, Yilmaz A, Cansever T, Cavusoglu $H$, Colak I, Genc HA, et al: Posterior lumbar interbody fusion versus posterolateral fusion with instrumentation in the treatment of low-grade isthmic spondylolisthesis: Midterm clinical outcomes. J Neurosurg Spine 14:488-496, 2011

23. Nguyen HV, Akbarnia BA, van Dam BE, Raiszadeh K, Bagheri R, Canale $S$, et al: Anterior exposure of the spine for removal of lumbar interbody devices and implants. Spine (Phila Pa 1976) $31: 2449-2453,2006$

24. Pan J, Li L, Qian L, Zhou W, Tan J, Zou L, et al: Spontaneous slip reduction of low-grade isthmic spondylolisthesis following circumferential release via bilateral minimally invasive transforaminal lumbar interbody fusion: Technical note and short-term outcome. Spine (Phila Pa 1976) 36:283-289, 2011

25. Ray CD: Threaded titanium cages for lumbar interbody fusions. Spine (Phila Pa 1976) 22:667-679; discussion 679-680, 1997

26. Sears W: Posterior lumbar interbody fusion for lytic spondylolisthesis: Restoration of sagittal balance using insert-and-rotate interbody spacers. Spine J 5:161-169, 2005

27. Smith JA, Deviren V, Berven S, Kleinstueck F, Bradford DS: Clinical outcome of trans-sacral interbody fusion after partial reduction for high-grade I5-s1 spondylolisthesis. Spine (Phila Pa 1976) 26:2227-2234, 2001

28. Spruit M, Pavlov PW, Leitao J, De Kleuver M, Anderson PG, Den Boer F: Posterior reduction and anterior lumbar interbody fusion in symptomatic low-grade adult isthmic spondylolisthesis: Short-term radiological and functional outcome. Eur Spine J 11:428-433, 2002
29. Steffee AD, Sitkowski DJ: Reduction and stabilization of grade IV spondylolisthesis. Clin Orthop Relat Res 227:82-89, 1988

30. Suk SI, Lee CK, Kim WJ, Lee JH, Cho KJ, Kim HG: Adding posterior lumbar interbody fusion to pedicle screw fixation and posterolateral fusion after decompression in spondylolytic spondylolisthesis. Spine (Phila Pa 1976) 22: 210-219; discussion 219-220, 1997

31. Taneichi $H$, Suda K, Kajino T, Matsumura A, Moridaira $H$, Kaneda K: Unilateral transforaminal lumbar interbody fusion and bilateral anterior-column fixation with two Brantigan I/F cages per level: Clinical outcomes during a minimum 2-year follow-up period. J Neurosurg Spine 4:198-205, 2006

32. Uzi EA, Dabby D, Tolessa E, Finkelstein JA: Early retropulsion of titanium-threaded cages after posterior lumbar interbody fusion: A report of two cases. Spine (Phila Pa 1976) 26: 1073-1075, 2001

33. Verlooy J, De SmedtK, Selosse P: Failure of a modified posterior lumbar interbody fusion technique to produce adequate pain relief in isthmic spondylolytic grade 1 spondylolisthesis patients. A prospective study of 20 patients. Spine (Phila Pa 1976) 18:1491-1495, 1993

34. Yashiro K, Homma T, Hokari Y, Katsumi Y, Okumura H, Hirano A: The Steffee variable screw placement system using different methods of bone grafting. Spine (Phila Pa 1976) $16: 1329-1334,1991$ 